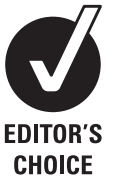

CHOICE
${ }^{1}$ Nutritional Epidemiology Group, Centre for Epidemiology and Biostatistics, University of Leeds, Leeds, UK

${ }^{2}$ Biostatistics Unit, Centre for Epidemiology and Biostatistics, University of Leeds, Leeds, UK

\section{Correspondence to}

Charlotte E L Evans, Nutritional Epidemiology Group, Centre for Epidemiology and Biostatistics, University of Leeds, Leeds LS2 9LN, UK;

c.e.l.evans@leeds.ac.uk

Accepted 25 January 2010

Published Online First

13 August 2010

\title{
SMART lunch box intervention to improve the food and nutrient content of children's packed lunches: UK wide cluster randomised controlled trial
}

\author{
C E L Evans, ${ }^{1}$ D C Greenwood, ${ }^{2}$ J D Thomas, ${ }^{1}$ C L Cleghorn, ${ }^{1}$ \\ M S Kitchen, ${ }^{1}$ J E Cade ${ }^{1}$
}

\section{ABSTRACT}

Background Government standards are now in place for children's school meals but not for lunches prepared at home. The aim of this trial is to improve the content of children's packed lunches.

Methods A cluster randomised controlled trial in 89 primary schools across the UK involving 1291 children, age 8-9 years at baseline. Follow-up was 12 months after baseline. A "SMART" lunch box intervention programme consisted of food boxes, bag and supporting materials. The main outcome measures were weights of foods and proportion of children provided with sandwiches, fruit, vegetables, dairy food, savoury snacks and confectionery in each packed lunch. Levels of nutrients provided including energy, total fat, saturated fat, protein, non-milk extrinsic sugar, sodium, calcium, iron, folate, zinc, vitamin $\mathrm{A}$ and vitamin $\mathrm{C}$.

Results Moderately higher weights of fruit, vegetables, dairy and starchy food and lower weights of savoury snacks were provided to children in the intervention group. Children in the intervention group were provided with slightly higher levels of vitamin A and folate. 11\% more children were provided with vegetables/salad in their packed lunch, and 13\% fewer children were provided with savoury snacks (crisps). Children in the intervention group were more likely to be provided with packed lunches meeting the government school meal standards.

Conclusions The SMART lunch box intervention, targeting parents and children, led to small improvements in the food and nutrient content of children's packed lunches. Further interventions are required to bring packed lunches in line with the new government standards for school meals.

Current controlled trials ISRCTN77710993.

Evidence exists that childhood obesity is related to dietary intake, in particular high intakes of energydense micronutrient-poor foods, sweetened drinks and low intakes of fibre. ${ }^{1}$ On a global scale, $10 \%$ of the world's school-aged children are now estimated to be carrying excess body fat, with an increased risk for developing chronic disease. ${ }^{2}$ Estimates of UK children's dietary intake reveal that the average diet of 7-10-year olds is high in fat and low in fruit and vegetables, ${ }^{3}$ contributing to the high, and increasing, prevalence of childhood obesity. ${ }^{4}$

One important setting for improving children's dietary intake is at school, ${ }^{2}$ leading to recent government action to improve school meals in the UK. Lunch accounts for $25-35 \%$ of the daily intake for children ${ }^{35} 6$ and therefore potentially plays an important role in a child's diet. From 2006 to 2009, food- and nutrient-based standards are to be introduced in primary and secondary school meals across all regions of the UK, further details of which are available from the School Food Trust. ${ }^{7}$ In summary, school meals must contain a portion of each of the following: fruit, vegetables or salad, dairy food, good quality meat, fish or other protein food and low fat starchy food such as potatoes or pasta. In addition, meals must not contain confectionery (cereal bars and any foods containing chocolate other than cocoa powder), savoury snacks (crisps) or sweetened or low-calorie drinks.

The new standards have resulted in significant improvements in meals provided by schools, ${ }^{8} 9$ with schools being regularly monitored to ensure that standards are maintained. ${ }^{10}$ Evidence exists of the potential of a more nutritious lunch to improve children's diets overall ${ }^{5}$; however, there are no standards enforced for packed lunches despite more than half of school children regularly consuming them. ${ }^{3}$ Packed lunches continue to be poor in terms of types of foods and nutrients, ${ }^{11}{ }^{12}$ and are particularly high in sodium and extrinsic (added) sugars.

A number of studies have been carried out in various countries with the intention of improving meals provided by schools ${ }^{13-16}$; however, a review of the literature reveals no trials aiming to improve packed lunches provided from home and taken/ eaten at school. The aim of this study is to conduct the first known cluster randomised controlled trial to improve the contents of packed lunches using an intervention named the "SMART" lunch box, thereby bringing packed lunches more in line with school meals meeting current government standards.

\section{PARTICIPANTS AND METHODS \\ Schools and children}

In 2006, we randomly selected and contacted 176 primary schools across the UK stratified by region, inviting them to participate in a study to improve children's packed lunches. All primary schools in the UK were eligible to enter the trial. A total of 89 schools agreed to participate, 76 from England, 6 from Wales, 4 from Scotland and 3 from Northern Ireland. Children from year 4 (age 8-9 years) and taking a packed lunch to school at least 1 day per week were eligible. If there was more than one class of year 4 pupils, one class was randomly selected 
and entered into the study. All schools gave informed written consent. All parents gave informed passive consent, which requires parents to sign and return a form if they refuse to allow their child to participate. Baseline data was collected from 1294 children attending all 89 schools in June 2006.

The schools were randomised into two groups: the full intervention group, which received the SMART lunch box and supporting materials (from here onwards referred to as the intervention group), or the minimal intervention group, which received a simple leaflet (from here on referred to as the control group). The random allocation of the schools was carried out using block randomisation within strata. Strata were based on two variables that may have an association with the contents of children's packed lunches, defined by the percentage of pupils entitled to free school meals (categorised into thirds) and achievement at key stage 2 (KS2: categorised into fifths). Children in England (but not Wales, Scotland or Northern Ireland) currently take exams in English, Maths and Science at age 11 when they are expected to reach level 4 in each subject. The mean KS2 result is the mean result for all pupils in year 6 in that school in 2005. Because concealment was not possible, the block length within each stratum was the total number of schools in that stratum. The intervention and control group each consisted of 44 schools. One school with three pupils in the trial consented but withdrew from the study before randomisation, due to school closure.

\section{Intervention}

The SMART lunch box intervention programme comprised of a lunch bag and two food boxes together with supporting materials for parents and children. At phase I (November 2006), families were given the SMART lunch box cooler bag, a large airtight SMART plastic food box for a sandwich or alternative, a small airtight SMART food box for small or chopped fruit, a Fruity Face for apples or similar fruit, a wall chart with ideas for packed lunches, a week of menus, a pad of blank shopping lists, and reward stickers. At phase II (February 2007), families were given an information leaflet on how to encourage their children to eat a wider range of packed lunch foods, recipes, a week of menus, a magnetic chart to record lunch foods, a magnetic lunch box, game and jokes, and facts about packed lunch foods. At phase III (beginning of March 2007), families were given a water bottle, cloth shopping bag with food ideas, a third week of menus, ideas for recipe books, a food game and a lunch chart. The materials are described in detail, with photos, on the project website. ${ }^{17}$ No food was provided to families. The main aims of the intervention were to encourage parents to provide foods from the five main food groups (starch, protein, dairy, vegetables and fruit) with water to drink, and in turn to encourage children to consume these foods. The intervention emphasised the need for an increase in nutrient-rich foods, but also included limited information on reducing savoury snacks and confectionery. The intention was to bring packed lunches in line with government food-based standards required to be met for school meals provided at school. Information on the government standards for school meals in all regions across the UK is discussed in detail in a previous publication. ${ }^{10}$

The control group (as well as the intervention group) received a simple one-page leaflet on how to improve children's packed lunches written by the School Food Trust. This is the usual level of information available to parents on improving packed lunches. CONSORT guidelines were followed, and ethics approval was granted by the University of Leeds.

\section{Objectives and outcome measures}

At baseline, 13 trained administrators visited all 88 schools. Before lunch, they weighed individual foods provided in each packed lunch using a specifically designed assessment tool. During lunch, they observed the children to assess any swapping of food items, and at the end of the lunchtime session all leftover food items were weighed individually. The information was entered into our in-house dietary assessment software, Dante (Diet and Nutrition Tool for Evaluation) based on the 6th edition of the Composition of Foods. ${ }^{18}$

Twelve months later in June 2007, follow-up data were collected from 971 children (75\% of baseline sample). As far as possible, the nature of the intervention was concealed from the administrators. Follow-up data were collected three full months after the third and final phase of the intervention. The primary outcome measures were the weights of food groups provided and the levels of 14 nutrients provided in the children's packed lunches. These results were compared with the food- and nutrient standards set for school meals

\section{Sample size and power}

To calculate sample size, we allowed for the fact that children within a school (cluster) may be more similar to each other than to children at a different school. Based on previous studies in similar age groups and similar dietary measures, ${ }^{16}{ }^{19-21}$ we assumed an intraclass correlation of 0.02 . To have $90 \%$ power to detect a reduction in per cent energy from fat by 1.5 percentage points would require 300 children completing the trial in each of two intervention groups. As far as possible, the trial was conducted and analysed according to the "intention-to-treat" principle; however, despite this, a small proportion would inevitably be lost to follow-up due to absence on the day of recording. Allowing for this, the aim was to have 360 children in the full intervention arm and 360 in the leaflet-only group. This objective was more than satisfied with 1291 children entering the trial.

\section{Statistical analysis}

All statistical analysis was carried out using multilevel modelling techniques to take account of the clustering of children within schools using MLwiN (version 2.02). ${ }^{22}$ Analysing this type of hierarchical data using multilevel modelling enables appropriate standard errors of the regression coefficients to be estimated.

Random intercept models were used, with food types and nutrients as the outcome variable, and fixed effects included. Certain micronutrients (sodium, calcium, iron, zinc, vitamin A and vitamin C) were transformed using the natural log due to non-normal distribution. To determine the intervention effects on foods and nutrients, an intercept was entered into the model (random) together with baseline level as a covariate (fixed) and two dummy variables for gender and intervention group (both fixed). CI values were obtained for foods and nutrients adjusted for gender to assess the size of intervention effects. Interaction effects between gender and intervention group were considered but were not significant, and were therefore excluded from all models. Interaction effects between two school-level variables, per cent free school meal eligibility (\%FSME) and key stage 2 SAT results (KS2 results), were also considered but were not significant, and were therefore excluded from all models. To determine the percentage of children who met each food or nutrient-based standard, multilevel binary models were used with no adjustment for baseline or gender in the model. For nutrient-based standards, each child was deemed to have met or 
not met each standard depending on whether the level was above or below the minimum or maximum level set by the government for primary school meals. For food-based standards, a simple binary score for food provided or not was used; therefore, each child was deemed to have met the standard if the restricted food was absent or if the permitted food was present, regardless of the weight of the food. For example, a child met the standard for vegetables whether they were provided with 10 or 100 g. $95 \%$ CI were also obtained.

\section{RESULTS}

Trial

Eighty-eight schools comprising 1291 children entered the trial. In the intervention group, five schools did not have follow-up data collected. This was due to two schools recruiting new head teachers in September 2006 and not wanting to continue with the trial. In addition, three schools had no follow-up data collected due to difficulties in arranging the administrator's visit. In total, 83 schools and 971 children completed the trial. The flow of schools and pupils through the trial are displayed in figures 1 and 2 .

\section{Food types}

At baseline, the control and intervention groups were similar in terms of weight of food types, with no evidence of imbalance between groups (table 1). Following the SMART lunch box intervention, higher weights of a number of food types were provided to children in the intervention group compared to the control group. These children were provided with more fruit, vegetables, dairy food (cheese and milk based desserts) and starchy food other than bread (mainly pasta). The mean weight of sandwiches and unsweetened drinks (pure fruit juice and milk) in the sample did not vary between the control and intervention group. Weight of savoury snacks (crisps and other salted snacks) was lower for children in the intervention group. However, weights of sweetened drinks (ready-made flavoured drinks and diluted squashes) and confectionery (foods containing chocolate, cereal bars and sweets) did not change

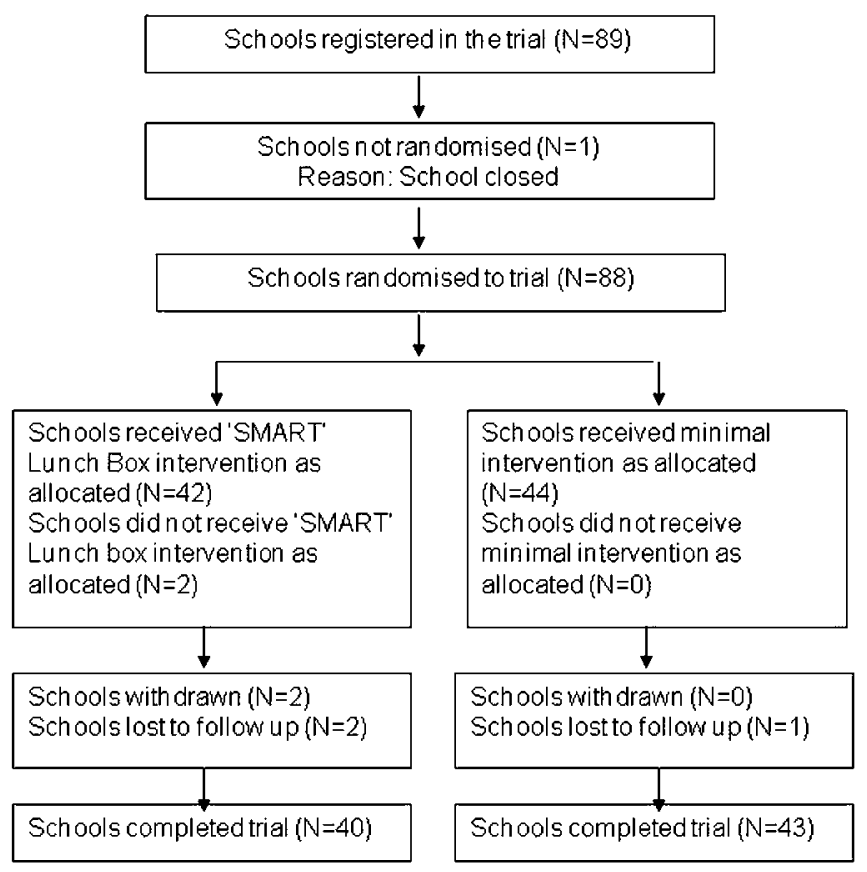

Figure 1 Flow of schools through the trial.

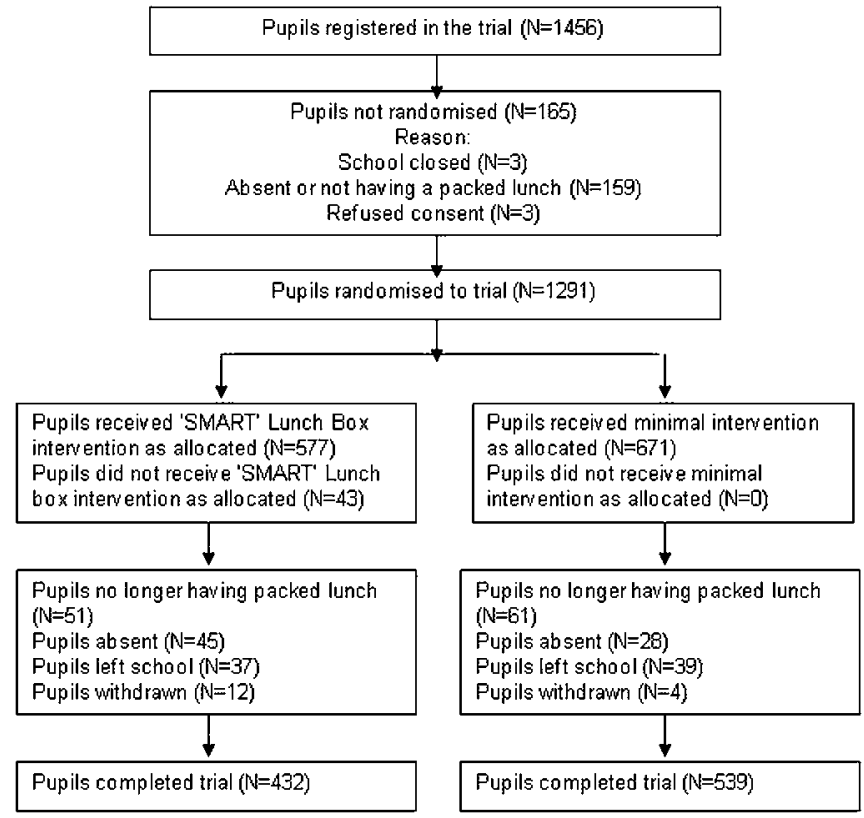

Figure 2 Flow of pupils through the trial.

(table 2). Weight of food types in the control group did not change between baseline and follow-up. ${ }^{23}$

The types of food included in the lunches were compared to the school meal food-based standards (table 3). The largest changes were in the proportion of children provided with vegetables (an increase of 11\%) and in those provided with savoury snacks (a decrease of 14\%). The total number of children meeting all the school meal food standards for England in the control group was $3(0.5 \%)$, compared to 16 in the intervention group $(3.7 \%)$.

\section{Nutrients}

At baseline, the control and intervention groups were similar in terms of levels of nutrients with no evidence of imbalance between groups (table 1). Higher levels of vitamin A and folate were provided to children in the intervention group. For all other nutrients, there were no differences between the intervention and control groups (table 4). Levels of nutrients in the control group did not change between baseline and follow-up. ${ }^{24}$

Nutrient levels were compared with the school meal nutrient standards (table 3 ). Children in the intervention group were no more likely to meet any individual nutrient standards compared with children in the control group. The mean number of nutrients met was six for children in the intervention and control groups. None of the children in the trial met all 14 of the nutrient standards for school meals. Children were most likely to meet the standard for protein, total carbohydrate and vitamin $\mathrm{C}$, and least likely to meet the standard for energy, sodium and non-milk extrinsic sugars (see table 3 ) in the intervention and control groups.

\section{Covariates}

All intervention effects were adjusted for gender and baseline levels. Boys and girls had similar weights of foods and nutrients at follow-up except for "other starchy food". Girls ate more alternatives to sandwiches, such as pasta, than boys, preintervention and post intervention, although both boys and girls had higher weights of this food in the intervention group compared to the control (data not shown). The effect size of the intervention was not associated with differences in school percentage 
Table 1 Baseline demographic and dietary data by intervention group for schools and pupils completing the trial

\begin{tabular}{|c|c|c|c|c|}
\hline Variable & Control $(n=539)$ & $95 \% \mathrm{Cl}$ & Intervention $(n=432)$ & $95 \% \mathrm{CI}$ \\
\hline \multicolumn{5}{|l|}{ Region } \\
\hline England & 36 & & 37 & \\
\hline Wales & 3 & & 2 & \\
\hline Scotland & 2 & & 0 & \\
\hline Northern Ireland & 2 & & 1 & \\
\hline \multicolumn{5}{|l|}{ School-level variables } \\
\hline${ }^{*}$ Free school meals (\%) & 14 & 4 to 20 & 16 & 4 to 21 \\
\hline${ }^{*}$ Key stage 2 results & 4.1 & 4.0 to 4.3 & 4.1 & 3.9 to 4.3 \\
\hline \multicolumn{5}{|l|}{ Individual-level variables } \\
\hline Male gender (\%) & 54.9 & & 49.3 & \\
\hline Sandwich (g) & 96.6 & 90.9 to 102.4 & 93.6 & 87.4 to 99.8 \\
\hline Other starchy food $(\mathrm{g})$ & 4.9 & 0.7 to 9 & 9.1 & 4.6 to 13.7 \\
\hline Cheese $(\mathrm{g})$ & 7.3 & 5.3 to 9.3 & 5.3 & 3.1 to 7.5 \\
\hline Milk-based desserts $(\mathrm{g})$ & 34.9 & 29.6 to 40.2 & 40.6 & 34.8 to 46.3 \\
\hline Fruit $(g)$ & 67.6 & 57.6 to 77.5 & 72.3 & 61.6 to 83 \\
\hline Vegetables (g) & 5.6 & 3.1 to 8.1 & 7.3 & 4.6 to 10 \\
\hline Unsweetened drinks $(\mathrm{g})$ & 108.3 & 88.5 to 128.1 & 93.3 & 72 to 114.6 \\
\hline Permitted desserts $(\mathrm{g})$ & 6.4 & 4.9 to 7.9 & 6.4 & 4.7 to 8.1 \\
\hline Savoury snacks (g) & 15.8 & 14.2 to 17.4 & 16.9 & 15.1 to 18.7 \\
\hline Confectionery $(\mathrm{g})$ & 23.3 & 20.7 to 25.9 & 22.1 & 19.3 to 24.9 \\
\hline Sweetened drinks $(\mathrm{g})$ & 201.6 & 179.6 to 223.6 & 225.0 & 201.3 to 248.7 \\
\hline Energy (E) (kcal) & 616.8 & 591.9 to 641.7 & 622.1 & 595.5 to 648.7 \\
\hline Protein $(\mathrm{g})$ & 17.7 & 16.7 to 18.8 & 18.1 & 17 to 19.1 \\
\hline Total fat $(\mathrm{g})$ & 21.0 & 19.7 to 22.3 & 20.3 & 18.9 to 21.6 \\
\hline Total fat $(\% \mathrm{E})$ & 29.7 & 28.6 to 30.7 & 28.8 & 27.6 to 29.9 \\
\hline Saturated fat $(\mathrm{g})$ & 8.1 & 7.6 to 8.7 & 7.9 & 7.4 to 8.5 \\
\hline Saturated fat $(\% \mathrm{E})$ & 11.5 & 11 to 12 & 11.1 & 10.6 to 11.6 \\
\hline Total carbohydrate $(\mathrm{g})$ & 94.3 & 90.4 to 98.2 & 97.2 & 93 to 101.3 \\
\hline Total sugar $(\mathrm{g})$ & 51.0 & 48.1 to 53.9 & 54.8 & 51.6 to 57.9 \\
\hline Non-milk extrinsic sugars $(\mathrm{g})$ & 38.0 & 35.5 to 40.6 & 41.4 & 38.7 to 44.2 \\
\hline Non-milk extrinsic sugars (\% E) & 22.9 & 21.5 to 24.2 & 24.9 & 23.4 to 26.3 \\
\hline Fibre (NSP) (g) & 3.6 & 3.4 to 3.7 & 3.9 & 3.7 to 4.2 \\
\hline †Sodium (mg) & 736.6 & 680.8 to 796.9 & 752.2 & 691.5 to 818.2 \\
\hline †Calcium (mg) & 221.0 & 203.3 to 240.1 & 240.1 & 219.6 to 262.5 \\
\hline †Iron (mg) & 2.2 & 2 to 2.3 & 2.3 & 2.1 to 2.5 \\
\hline †Zinc (mg) & 1.8 & 1.7 to 1.9 & 2.0 & 1.8 to 2.1 \\
\hline †Folate $(\mu \mathrm{g})$ & 45.1 & 41.7 to 48.7 & 50.7 & 46.6 to 55.1 \\
\hline †Vitamin C (mg) & 29.0 & 25.2 to 33.4 & 35.3 & 30.4 to 41.1 \\
\hline †Vitamin A $(\mu \mathrm{g})$ & 63.6 & 53 to 76.2 & 88.1 & 72.4 to 107.1 \\
\hline
\end{tabular}

*Median and IQR.

†Nutrient log transformed.

NSP, non-starch polysaccharides.

of free school meal eligibility for any food or nutrient (data not shown).

\section{DISCUSSION}

The aim of the SMART lunch box intervention programme was to improve the quality of packed lunches, thereby bringing them in line with school meals meeting the new government standards, which vary slightly by region in the UK. ${ }^{10}$ The new standards, which are based on dietary evidence to reduce the risk of coronary heart diseases and cancer, were devised to improve children's diets for long-term health, and promote a diet higher in fruit, vegetables and fibre, and lower in saturated fat and sodium. 2526

Our trial was partly successful in closing the existing gap between school lunches meeting the new school meal standards and packed lunches. 89 Parents in the SMART lunch box intervention group increased the amount of fruit and vegetables and dairy food provided to children by moderate amounts, resulting in small improvements in the provision of vitamin A and folate.
The increase in fruit and vegetables rich in micronutrients did not result in a concomitant increase in fibre or zinc. Combining fruit and vegetable weights, the impact of the intervention was an average increase of a third of a portion of fruit and vegetables provided to children at lunchtime. The increase resulted from some children having larger portion sizes of vegetables and also from a doubling in the proportion of children being provided with vegetables. The proportions of children in the control group provided with fruit are similar to those obtained in the 2004 lunch box survey ${ }^{12}$ (52\%), although more children in 2004 were provided with savoury snacks (69\%) and fewer were provided with confectionery (58\%). Children in the intervention group were less likely to have snack food and more likely to have fruit and vegetables than in the 2004 survey.

The results are similar in scale to intervention studies aiming to improve school meals. ${ }^{16} 27-30$ Improving fruit and vegetable consumption in packed lunches is dependent on behaviour change from children and parents, making it more challenging to generate dietary change compared to improving school meal 
Table 2 Mean weights and intervention effect of foods provided in packed lunches at follow-up, adjusted for gender and baseline level

\begin{tabular}{|c|c|c|c|c|c|c|c|}
\hline \multirow[b]{2}{*}{ Food type } & \multicolumn{2}{|c|}{ Control $(n=539)$} & \multicolumn{2}{|c|}{ Intervention $(n=432)$} & \multicolumn{3}{|l|}{ Intervention effect } \\
\hline & Mean & $95 \% \mathrm{Cl}$ & Mean & $95 \% \mathrm{Cl}$ & Mean difference & 95\% Cl of difference & p Value \\
\hline Sandwich (g) & 100.5 & 88.8 to 112.2 & 103.7 & 91.4 to 116 & 3.2 & -4.7 to 11.1 & 0.43 \\
\hline Other starchy food $(\mathrm{g})$ & -5.1 & -15.3 to 5.1 & 2.4 & -8.3 to 13.1 & 7.4 & 0.5 to 14.4 & 0.04 \\
\hline Cheese $(\mathrm{g})$ & 7.3 & 3.5 to 11.1 & 10.2 & 6.1 to 14.2 & 2.9 & -0.1 to 5.9 & 0.06 \\
\hline Milk-based desserts (g) & 39.2 & 29.5 to 48.8 & 44.8 & 34.7 to 54.9 & 5.6 & -0.4 to 11.6 & 0.07 \\
\hline Fruit $(\mathrm{g})$ & 65.9 & 48.3 to 83.6 & 80.5 & 62 to 99.1 & 14.6 & 0.8 to 28.4 & 0.04 \\
\hline Permitted desserts $(\mathrm{g})$ & 3.6 & 0.1 to 7 & 3.9 & 0.3 to 7.6 & 0.3 & -2.1 to 2.8 & 0.78 \\
\hline Confectionery (g) & 24.0 & 19 to 29 & 22.0 & 16.7 to 27.2 & -2.1 & -5.6 to 1.5 & 0.26 \\
\hline Savoury snacks (g) & 16.5 & 13 to 20 & 13.6 & 10 to 17.3 & -2.8 & -5.5 to -0.2 & 0.04 \\
\hline Sweetened drinks $(\mathrm{g})$ & 202.1 & 164.1 to 240.1 & 197.1 & 157 to 237.2 & -5.0 & -34.3 to 24.4 & 0.74 \\
\hline
\end{tabular}

intake. Although the individual improvements are small, in epidemiological terms, a moderate sustained increase in fruit and vegetable intake at one meal event may have health benefits at a population level.

Despite the emphasis on starchy foods and drinking water, the weight of sandwiches and sweetened drinks did not change. In addition, the levels of fats, sugars and sodium did not improve in the intervention children. These are disappointing results as the extrinsic sugar levels were particularly high in this population. The SMART lunch box intervention primarily focused on improving nutrient-rich foods with less attention on reducing energy dense foods. An attempt to improve the acceptability of this intervention to parents and children, by concentrating on the positive, may have weakened the impact of the intervention. Interventions aimed at children that concentrate equally on an increase in healthy foods and a decrease in unhealthy foods may be more successful.

Larger improvements in weights of food types are needed to generate improvements in the nutrient profile. However, further difficulties arise in improving the nutrient profile when nutrientrich foods, such as dairy foods, which are encouraged, contain high levels of restricted nutrients-for example, cheese high in

Table 3 School meal standards for nutrients and foods at follow-up, with proportion of children in intervention and control groups meeting each standard

\begin{tabular}{|c|c|c|c|c|c|c|}
\hline \multirow[b]{2}{*}{ Nutrient or food type } & \multicolumn{2}{|c|}{ Government school meal standards for England } & \multicolumn{2}{|l|}{ Control } & \multicolumn{2}{|c|}{ Intervention } \\
\hline & $\begin{array}{l}\text { Primary school } \\
\text { nutrient standard }\end{array}$ & Description & $\begin{array}{l}\text { Per cent } \\
\text { meeting } \\
\text { standard }\end{array}$ & $95 \% \mathrm{Cl}$ & $\begin{array}{l}\text { Per cent } \\
\text { meeting } \\
\text { standard }\end{array}$ & $95 \% \mathrm{Cl}$ \\
\hline Protein food & 1 portion & Good-quality meat or fish & 71.6 & 67.3 to 75.5 & 75.1 & 70.5 to 79.2 \\
\hline Dairy food & 1 portion & As part of main course or dessert & 52.1 & 46.7 to 57.5 & 60.6 & 54.8 to 66.1 \\
\hline Fruit & 1 portion & Fresh or tinned in juice & 53.7 & 47.1 to 60.1 & 58.9 & 51.9 to 65.5 \\
\hline Vegetables & 1 portion & Salad or cooked & 15.7 & 11.9 to 20.2 & 27.0 & 21.4 to 33.3 \\
\hline Drinks & Permitted & Water, fruit juice and milk permitted & 26.3 & 21.1 to 32.2 & 28.0 & 22.3 to 34.5 \\
\hline Desserts & Permitted & Can contain cocoa powder as flavouring & 11.0 & 8 to 14.8 & 13.7 & 10 to 18.5 \\
\hline Sweetened drinks & Restricted & $\begin{array}{l}\text { No sweetened or low-calorie flavoured } \\
\text { drinks permitted }\end{array}$ & 39.7 & 33.1 to 46.3 & 39.6 & 32.5 to 46.7 \\
\hline Protein $(\mathrm{g})$ & 7.5 & Minimum & 92.9 & 89.5 to 95.2 & 94.9 & 91.7 to 96.9 \\
\hline Total fat $(\mathrm{g})$ & 20.6 & Maximum & 56.6 & 51.7 to 61.3 & 55.9 & 50.6 to 61.1 \\
\hline Saturated fat $(\mathrm{g})$ & 6.5 & Maximum & 44.0 & 39.8 to 48.2 & 44.4 & 39.8 to 49.2 \\
\hline Total carbohydrate $(\mathrm{g})$ & 70.6 & Minimum & 71.2 & 65.7 to 76.1 & 75.8 & 70.3 to 80.6 \\
\hline Non-milk extrinsic sugars $(\mathrm{g})$ & 15.5 & Maximum & 20.4 & 16.3 to 25.3 & 17.1 & 13.1 to 22 \\
\hline Fibre (NSP) (g) & 4.2 & Minimum & 31.3 & 25.9 to 37.3 & 37.2 & 31 to 43.9 \\
\hline Vitamin A $(\mu \mathrm{g})$ & 175 & Minimum & 22.8 & 18.6 to 27.6 & 28.9 & 23.8 to 34.6 \\
\hline Vitamin C (mg) & 10.5 & Minimum & 80.6 & 76 to 84.5 & 83.7 & 79 to 87.5 \\
\hline Sodium (mg) & 499 & Maximum & 18.9 & 15.1 to 23.4 & 19.5 & 15.3 to 24.5 \\
\hline Calcium (mg) & 193 & Minimum & 61.4 & 55.9 to 66.6 & 63.1 & 57.2 to 68.6 \\
\hline Folate $(\mu \mathrm{g})$ & 53 & Minimum & 41.2 & 35.5 to 47.1 & 44.8 & 38.6 to 51.2 \\
\hline Iron (mg) & 3.0 & Minimum & 22.7 & 18.4 to 27.5 & 26.1 & 21.2 to 31.7 \\
\hline
\end{tabular}

NSP, non-starch polysaccharides. 
Table 4 Levels and intervention effect of nutrients provided in packed lunches at follow-up, adjusted for gender and baseline level

\begin{tabular}{|c|c|c|c|c|c|c|c|}
\hline \multirow[b]{2}{*}{ Nutrient } & \multicolumn{2}{|l|}{ Control } & \multicolumn{2}{|c|}{ Intervention } & \multicolumn{2}{|c|}{ Intervention effect } & \multirow[b]{2}{*}{ p Value } \\
\hline & $n=539$ & $95 \% \mathrm{Cl}$ & $n=432$ & $95 \% \mathrm{Cl}$ & $\begin{array}{l}\text { Mean } \\
\text { difference }\end{array}$ & 95\% Cl of difference & \\
\hline Energy (E) (kcal) & 593.1 & 549.5 to 636.7 & 607.4 & 561.5 to 653.3 & 14.3 & -20.9 to 49.5 & 0.43 \\
\hline Total fat $(\mathrm{g})$ & 19.8 & 17.4 to 22.1 & 20.1 & 17.6 to 22.6 & 0.3 & -1.4 to 2 & 0.70 \\
\hline Total fat $(\% \mathrm{E})$ & 28.7 & 26.6 to 30.8 & 28.4 & 26.2 to 30.6 & -0.3 & -1.6 to 1 & 0.63 \\
\hline Saturated fat $(\mathrm{g})$ & 7.6 & 6.6 to 8.7 & 8.1 & 7 to 9.2 & 0.4 & -0.3 to 1.2 & 0.24 \\
\hline Total sugar $(\mathrm{g})$ & 53.0 & 48.1 to 57.9 & 53.3 & 48.1 to 58.4 & 0.3 & -3.2 to 3.7 & 0.89 \\
\hline Non-milk extrinsic sugars (g) & 38.9 & 34.3 to 43.5 & 38.5 & 33.6 to 43.3 & -0.4 & -4 to 3.2 & 0.82 \\
\hline Non-milk extrinsic sugars (\% E) & 24.0 & 21.4 to 26.6 & 23.8 & 21 to 26.5 & -0.2 & -2.2 to 1.8 & 0.83 \\
\hline Fibre (NSP) (g) & 3.1 & 2.6 to 3.7 & 3.4 & 2.8 to 4 & 0.3 & -0.1 to 0.7 & 0.21 \\
\hline *Sodium (mg) & 777.4 & 686.4 to 880.6 & 805.1 & 706.2 to 918 & 27.8 & -52.1 to 116.6 & 0.51 \\
\hline *Vitamin C (mg) & 30.8 & 23.9 to 39.8 & 36.0 & 27.5 to 47.1 & 5.1 & -1.1 to 12.7 & 0.11 \\
\hline${ }^{*}$ Vitamin A $(\mu \mathrm{g})$ & 57.5 & 41.3 to 80.0 & 78.0 & 55.1 to 110.4 & 20.6 & 3.0 to 43.4 & 0.02 \\
\hline
\end{tabular}

${ }^{*}$ Nutrient log transformed.

NSP, non-starch polysaccharides.

sodium and saturated fat, and milk-based desserts high in extrinsic sugars. Concomitantly, a reduction in savoury snacks containing starch and fibre may have negated any improvement in fibre provision as a result of the increase in fruit and vegetables.

Boys' energy provision was not higher than girls, as may be expected for this age group from results of both previous studies on school meals ${ }^{3}{ }^{31}$ and the Estimated Average Requirement for this age group. ${ }^{32}$ Our study is very accurate due to the weighing of all food, and this lack of difference may be a consequence of many packed lunch food items only made available in predetermined packets. At older ages, this could potentially lead to an underconsumption in boys and/or an overconsumption in girls, although children may compensate by eating more or less at other times of the day.

This is the first national study to weigh packed lunch food and so provides an accurate estimate of food provided and consumed by primary school children. The study did have notable limitations. Many schools declined to participate in the study when first approached. However, attempts were made to reduce potential bias by replacing schools, which had declined, with similar types of schools in terms of levels of deprivation. Of equal concern was the large number of schools that did not have follow-up data collected. Schools that were particularly keen to promote school meals and therefore less involved in the lunch box intervention were reluctant to complete the trial despite repeated attempts to arrange data collection, a problem due to the timing of the trial. This could have led to biased results. A further weakness of the study was that only one meal was assessed as opposed to nutritional intake over the whole day. Increases at lunchtime may have reduced intake of fruit and vegetables outside of school. However, the intervention was low cost and did not involve a large effort for teachers, and therefore offers a potentially useful way of improving children's lunches.

Although there were moderate improvements in the types of food provided, packed lunches still remained of poor quality compared with school meals meeting the current standards. ${ }^{8} 9$ Popular packed lunch foods such as bread, ham, cheese, tuna, yoghurts, cakes, biscuits and crisps are traditionally high in sodium or non-milk extrinsic sugars. Therefore, to enable parents to easily provide a lunch that meets the school meal standards, changes may be required at the manufacturing stage.

Alternatively, increasing uptake of school meals can potentially improve dietary quality for more school children. Initiatives are in place to further increase the uptake of school meals by offering free school meals to all children. However, a quarter of children prefer to take a packed lunch even when offered a free school meal. ${ }^{33}$ It is therefore important that initiatives to improve the nutrient content of packed lunches are not excluded from the government's plans to improve children's diets.

From September 2008, the UK government strategy document to tackle obesity rates ${ }^{34}$ states that all schools must have a policy on packed lunches. To considerably improve the provision of certain food types, policies at the school level may be necessary, such as encouraging parents to provide children with some starchy food and fruit and vegetable in their lunch, restricting snacks and providing water at school for children

\section{What is already known on this subject}

Packed lunches are of poor quality in the UK compared to school meals following the recently introduced government standards for primary and secondary school meals. Improving lunchtime nutritional intake in children can lead to improvements in overall nutritional intake.

\section{What this study adds}

It is possible to design and implement a simple intervention to improve the food content of children's packed lunches. More research is needed to identify additional more effective ways of reducing the gap between packed lunches and school meals. 
having packed lunches. The proportion of children in the intervention meeting all the school meal food standards remained very low, an indication that school policy as well as innovative and more powerful interventions are necessary.

Before school meal standards were introduced in 2006, teenagers regularly taking a packed lunch compared to those taking a school meal were found to have more risk factors for developing coronary heart diseases such as higher blood pressure. ${ }^{35}$ The recent improvements in school meals and the lack of improvement in packed lunches suggests that the health gap between young people taking a school meal and packed lunch is likely to widen in the future. The accumulating evidence linking poor health in adulthood with poor diet and/or obesity in childhood $^{36-38}$ emphasises the importance of further research in this area.

\section{CONCLUSIONS}

A simple school-based intervention resulted in a moderate improvement in the food content of children's packed lunches but little improvement in the nutrient profile. Additional research is needed to further reduce the gap between school meals and packed lunches in UK primary school children.

Acknowledgements This study was commissioned by the Food Standards Agency, project reference N14R0004. We are extremely grateful to all the participating schools, pupils and families for their enthusiasm and time devoted to the trial. We are indebted to The National Foundation for Educational Research, which recruited schools and collected all packed lunch data, and to Dr Emma Harvey for providing essential support on trial management.

Funding Food Standards Agency, London, UK.

\section{Competing interests None.}

Ethics approval This study was conducted with the approval of the University of Leeds.

Contributors CELE managed the day-to-day running of the project and wrote the first draft of the paper. DCG provided statistical support from the design stage to the completion of the project. CELE, CLC and MSK designed the intervention. JDT designed the data management system. JEC secured funding, supervised the project, and was guarantor for the project. All authors contributed to the final version of the paper.

Provenance and peer review Not commissioned; not externally peer reviewed.

\section{REFERENCES}

1. Swinburn BA, Caterson I, Seidell JC, et al. Diet, nutrition and the prevention of excess weight gain and obesity. Public Health Nutr 2004;7:123-46.

2. Lobstein T, Baur L, Uauy R. Obesity in children and young people: a crisis in public health. Obes Rev 2004;1(5 Suppl):4-104.

3. Gregory J, Lowe S, Bates CJ, et al. National diet and nutrition survey (NDNS): young people aged 4 to 18 years 2000 London: The Stationery Office.

4. Chinn S, Rona RJ. Prevalence and trends in overweight and obesity in three cross sectional studies of British Children, 1974-94. BMJ 2001;322:24-6.

5. Rogers IS, Ness AR, Hebditch K, et al. Quality of food eaten in English primary schools: school dinners vs packed lunches. Eur J Clin Nutr 2007:61:856-64.

6. Ruxton CHS, Kirk TR, Belton NR. The contribution of specific dietary patterns to energy and nutrient intakes in 7-8 year old Scottish schoolchildren. II. Weekday lunches. J Hum Nutr Diet 1996;9:15-22.

7. School Food Trust. Revised guide to standards for school lunches, 2008. http:// www.schoolfoodtrust.org.uk/parents-carers/resources/revised-guide-to-standards for-school-lunches (accessed Jul 2010)

8. Rees GA, Richards CJ, Gregory J. Food and nutrient intakes of primary school children: a comparison of school meals and packed lunches. J Hum Nutr Diet 2008;21:420-27.

9. School Food Trust. Children's lunchtime choices following the introduction of foodbased standards for school lunch; observations from six primary schools in Sheffield,
2007. http://www.schoolfoodtrust.org.uk/schools/reports/school-lunch-and-learningbehaviour-in-primary-schools-baseline-dietary-data (accessed Jul 2010).

10. Evans C, Harper C. A history and review of school meal standards in the UK. J Hum Nutr Diet 2009;22:89-99.

11. Jefferson A, Cowbrough K. School lunch box survey 2003. Food Standards Agency 2003. http://www.food.gov.uk/multimedia/pdfs/lunchsurvey.pdf. (accessed Jul 2010).

12. Jefferson A, Cowbrough K. School lunch box survey 2004. Food Standards Agency 2004. http://www.food.gov.uk/multimedia/pdfs/lunchbox2004report.pdf laccessed Jul 2010).

13. Lowe CF, Horne PJ, Hardman CA, et al. A peer-modeling and rewards-based intervention is effective in increasing fruit and vegetable consumption in children. Prev Med 2006;43:351.

14. Haerens $\mathbf{L}, \mathrm{De} B \mathrm{Bl}$, Maes $\mathrm{L}$, et al. The effects of a middle-school healthy eating intervention on adolescents' fat and fruit intake and soft drinks consumption. Public Health Nutr 2007:10:443-9.

15. Nicklas TA, O'Neil CE. Process of conducting a 5-a-day intervention with high school students: Gimme 5 (Louisiana). Health Educ Behav 2000;27:201-12

16. Sahota P, Rudolf MC, Dixey R, et al. Randomised controlled trial of primary school based intervention to reduce risk factors for obesity. BMJ 2001;323:1029-32

17. Evans CEL. The SMART lunch box project website, available until at least 13.10.10 October 2008. http://www.smartlunchbox.co.uk (accessed 28 May 2009).

18. Royal Society of Chemistry. McCance and Widdowson's the composition of foods: summary edition. London: HMSO, 2002

19. Rudolf MC, Greenwood DC, Cole TJ, et al. Rising obesity and expanding waistlines in schoolchildren: a cohort study. Arch Dis Child 2004;89:235-7.

20. Rudolf MC, Cole TJ, Krom AJ, et al. Growth of primary school children: a validation of the 1990 references and their use in growth monitoring. Arch Dis Child 2000;83:298-301.

21. Rudolf MC, Sahota $\mathrm{P}$, Barth $\mathrm{JH}$, et al. Increasing prevalence of obesity in primary school children: cohort study. BMJ 2001;322:1094-5.

22. Rasbash J, Browne W, Goldstein H, et al. A user's guide to MLwiN 2.10 ed. Bristol: University of Bristol, 2001.

23. Evans C, Thomas JD, Harvey E, et al. A cluster randomised controlled trial of a Smart lunch box, designed to improve the content of primary school children's packed lunches in the UK: final report 2008. http://www.foodbase.org.uk/results. php?f_category_id=\&f_report_id=92 (accessed 27 Sept 2010).

24. Evans CEL, Greenwood DC, Thomas JD, et al. A cross-sectional survey of children's packed lunches in the UK: food- and nutrient-based results. JECH Published Online First: 20 Jan 2010. http://jech.bmj.com/content/early/2010/01/13/jech.2008.085977. full.pdf (accessed Jul 2010).

25. Brunner EJ, Thorogood M, Rees K, et al. Dietary advice for reducing cardiovascula risk. Cochrane Database Syst Rev 2005:CD002128.

26. Greenwald $\mathbf{P}$, Clifford CK, Milner JA. Diet and cancer prevention. Eur J Cancer 2001;37:948-65.

27. Baranowski T, Davis M, Resnicow K, et al. Gimme 5 fruit, juice, and vegetables fo fun and health: outcome evaluation (erratum appears in Health Educ Behav 2000 Jun;27(3):390). Health Educ Behav 2000;27:96-111.

28. Auld GW, Romaniello C, Heimendinger J, et al. Outcomes from a school-based nutrition education program alternating special resource teachers and classroom teachers. J Sch Health 1999;69:403-8.

29. Nicklas TA, Johnson CC, Myers L, et al. Outcomes of a high school program to increase fruit and vegetable consumption: Gimme 5-a fresh nutrition concept for students. J Sch Health 1998;68:248-53.

30. Baranowski T, Baranowski J, Cullen KW, et al. Squire's quest! Dietary outcome evaluation of a multimedia game. Am J Prev Med 2003:24:52-61.

31. Department of Health. The diets of British school children. London: Her Majesty's Stationery Office, 1989.

32. Department of Health. Dietary reference values for food energy and nutrients for the United Kingdom. HMSO 1991.

33. The Scottish Government Publications. School meals in Scotland 2008. 2008.

34. Cross-Government Obesity Unit. Healthy weight, healthy lives: a crossgovernment strategy for England, 2008. http://www.dh.gov.uk/en/ Publicationsandstatistics/Publications/PublicationsPolicyAndGuidance/DH 082378 (accessed Jul 2010).

35. Whincup PH, Owen CG, Sattar N, et al. School dinners and markers of cardiovascular health and type 2 diabetes in 13-16 year olds: cross sectional study. BMJ 2005;331:1060-1.

36. Baker JL, Olsen LW, Sorensen TI. Childhood body-mass index and the risk of coronary heart disease in adulthood. N Engl J Med 2007;357:2329-37.

37. Frank GC, Berenson GS, Webber LS. Dietary studies and the relationship of diet to cardiovascular disease risk factor variables in 10-year-old children-the Bogalusa heart study. Am J Clin Nutr 1978;31:328-40.

38. Must A, Strauss RS. Risks and consequences of childhood and adolescent obesity 4 Int J Obes Relat Metab Disord 1999:23(Suppl 2):S2-11. 